\title{
Multidimensional Analysis of Ethical Leadership for Business Development
}

\author{
By Jiř́ Bláha ${ }^{1}$, Lucjan Klimsza ${ }^{1}$, Aleš Lokaj ${ }^{1}$, Lech Nierostek $^{1}$
}

\begin{abstract}
Tremendous progress has been made in industry including artificial intelligence, robotics and $4^{\text {th }}$ generation of industry. People in most countries work smarter, hard work is supplied by machines and automatics do constantly repeated operations. Modern technology has made work smarter, quicker and more precise than human works. But there are still many problems to tackle. Tension on effective work is much than higher. Companies prioritize well educated people. The value of the company is measured not only by the level of financial capital, either intellectual capital is also rated. There are economic reasons for prioritizing effectivity in industrial development, and intellectual capital increasing level of effectivity. On the other hand, there are some arguments for prioritizing social and ethical responsibility. Economic growth could not be the only reason for development in business. In addition, involvement in corruption scandals and environmental accidents can severely damage the reputation of a company. Innovation in management is needed. Some results of investigations in that area suggested that ethical leadership could gain negative consequences of human behavior. Finally, it has been found that the development in ethical leadership could bring the benefits for employee and employers and can increase level of productivity and thus profits of companies. The main aim of the article is to describe an investigation of ethical leadership influence on companies.
\end{abstract}

Keywords: Axiology, economics, ethics, ethical leadership, intellectual capital, philosophy of values, values

\section{Introduction}

Ethical leadership represents a new way in a human resources management (HR management). Expected outputs and impacts of ethical leadership on economics and economical behaviour or organizations are not yet clearly described. This topic is described in many professional books though but a detailed research of this area, especially in the Czech environment, is absent. At the same time, more detailed study shows that as it comes to terminology of this area, it is not unified yet. Even though for Human resources management ethical leadership represents quite huge potential. Organization, which implements such managerial approach can develop in many areas such as $\mathrm{HR}$ management, strategic management as well as in work with human capital. And, at the same time, ethical leadership can have huge impact on economical operation and economical behaviour of organization. The impact of ethical leadership on Industry 4.0 can become a significant problem.

In this article, the research team acquaints with a research dealing with ethical leadership, which is prepared to take place in April 2020. This article involves a pilot study, the aim of which was to test whether the questions regarding the ethical values are understandable; 
small sample of the company with up to 10 employees was used. The research in the field of ethical leadership is such peculiar that many professionals of more scientific fields were needed to become involved. This research is interdisciplinary and scientists of economics, management, psychology and value philosophy took part in it.

The first chapter of the article is devoted to methodology determination, content of being prepared research, methods. The second chapter deals with leadership as such and ethical leadership. In the third chapter relation between ethical leadership and human capital is presented. The fourth chapter involves the pilot study.

\section{Methodology of Ethical Leadership Research}

All impacts of ethical leadership on company's economic results have not only been thoroughly studied but yet epistemological basis of ethical management and impact on human capital has not been described either. Foreign literature shows tries to grasp the ethical leadership and find epistemological basis for this new type of management. Current literature thus indicates that for this type of management, basis is being seeking for quite difficultly. The interdisciplinary dimension of ethical management is the reason for such fact.

Interdisciplinary approach is nothing radically new. It is interconnection of different fields, which put a particular phenomenon under a research. With such work though, there comes a problem along namely connection of different methods and detailed methodologies; by their interconnection, an explanation of a certain phenomenon should be discovered and in the best case, contribution to a given field should be pointed out or even determined solutions offered. Finding the methodology based on interdisciplinarity is easier if such method is found within the natural or social sciences. In this case, social science is considered, thus common methodology is difficult to find but not impossible. František Ochrana describes this methodological approach in his book Metodologie vědy and defines it precisely as a functionally-objective research aim (Ochrana, 2009, p. 13). The functionally-objective aim is a combination of analytical methods and implementation methods elaborated to implement new procedures leading to improvement of organizational culture or management processes in a company.

As said above, this topic cannot be researched only from one field's point of view. Such research is possible though but it does not express this problem compactly. This article tries to point out the impacts of ethical leadership on human capital in organization as well as on economic contribution to manufactures. The subject of research, ethical leadership is and its contribution to other fields namely management and economics. This is the reason why we have called our research multidimensional. Scientists of economics, HR management, management and philosophy became involved in this research.

During the analysis, relation between particular marks will be sought. Data correlation collected for certain marks and which will be analyzed from the perspective of different fields, enables to understand the problem of ethical leadership in relation to the economic indicators of companies. Once recurring relationships are found, e.g. between ethical conduct and the level of communication within an organization, a certain judgment will be drawn from these relationships. "One possible form of scientific explanation in the social sciences is an explanation based on the scientific law - or a form of subsumption 
under the scientific law. By law is meant a substantial, relatively stable, recurring relationship under given conditions. If this relationship is revealed, scientifically explained and defined by the means of science, we call it the scientific law" (Ochrana, 2009, p. 68). The scientific law will be formulated as a logical judgment. This judgment will follow the rules of logical implication. The logical structure is as follows (Ochrana, 2009, p. 68).

Logical structure of logical law:

$\forall x(P(x) \rightarrow Q(x))$

Legenda:

$\forall x$ universal quantificator: for all $\mathrm{x}$ applies that.

$P(x)$ implication antecedent expressing implication conditions $\mathrm{P} 1(\mathrm{x}) \wedge \mathrm{P} 2(\mathrm{x}) \wedge \mathrm{Pk}(\mathrm{x})$. $\mathrm{Q}(\mathrm{x})$ implication consequent.

If the number of repeating attributes $(\mathrm{P} 1, \mathrm{P} 2 \ldots \mathrm{Pk})$ of a certain mark $(\mathrm{x})$ is the same and always repeating under certain conditions, then we will be able to determine a judgment of general application. The mark (x) means the mark that characterizes ethical leadership.

\subsection{Content Determination of Forthcoming Research}

The multidimensional analysis of ethical leadership for economic contribution is based on a comparison of ethical indicators with economic indicators in the company. By ethical indicators, ethical norms and values are meant involving four areas:

personal values, organization cultural values, consumer values, social values.

Personal values or, in other authors individual values, express that the man have responsibility towards himself or other people. Arno Anzenbacher describes this fact in the following way: "Often, there is individual and social etbics distinguished. Distinction of two areas of individual conscience motivation is meant. Individual ethics is considered when I am motivated by something what is touched to my individual perfection or to welfare of another individual. (...). Thus, individual ethics always considers individual aim of individual person" (Anzenbacher, 1991, p. 251n.). This responsibility can be expressed by values such as freedom, self-confidence and selfrealization at work.

The term organization culture values is very complicated because it involves the whole scope of responsibilities. Arno Anzenbacher again says that "Social ethics then examines the duties that are imposed on man if he is to perform a partial function in a whole created for the common good. (...) In social etbics, it is always a common goal, a common good, something to be realized in collaboration with more people" (Anzenbacher, 1991, p. 252.). Organization culture values are based on the awareness of the responsibilities of a certain group or collective. In our research, we build on this idea and further refine it so that we can determine the level of organization's responsibility to its employees. This responsibility can be expressed by values such as: employer's responsibility for employees, belonging, recognition for work, credibility of the business in the market.

Customer values are based on the definition of an organization that deals with the transformation of resources into goods to meet other's needs. We start from the premise that the manufacturing company creates values that satisfy other's needs. For this reason, we have called the relationships that arise during the satisfaction of other's needs as 
consumer values. This area is based on stakeholder theory; probably the best known and one of the first definitions is the definition of R. E. Freeman (2005), according to which a modern enterprise should take the rights and needs of the stakeholder into account. In the research, we focused on the key stakeholder - customers.

Social values reflect the degree of influence an organization has on the environment in which it operates. We understand the term environment very broadly, that is, the region and the local communities that live in that region. Furthermore, the environment and remediation caused by the activities of the organization, as well as activities related to the restoration of e.g. greenery in cities. Another influence is the involvement in charitable activities, support of schools and sports teams at the youth level, etc. In this area we find the basis in the concept of Corporate Social Responsibility (CSR); its definition, not always uniform, is submitted by many authors. From these we choose the definition of Business Leaders Forum, which we consider apt: "The concept of Corporate Social Responsibility (CSR) emerged in the latter half of the 20th century. Corporate social responsibility means management and relationship building with partners to improve the image and increase credibility of the company. For members of the Business Leaders Forum, corporate social responsibility is a voluntary commitment by firms to be responsible towards the environment and society in which they operate."

These ethical standards and values correspond to economic indicators. These indicators can be further measured and compared with each other. For more details see Table 1.

\subsection{Research Methods}

Defining and setting values (not only ethical values) is therefore an important part of any organization. In his book Bachmann (2017) deals with ethical treatment with employees, ethical behavior towards customers, suppliers and ethical behavior towards competitors. We also divide these areas into four basic areas of standards and values that are important to the business. Unlike Bachmann, however, we are not only concerned with the relationship between the organization and its surroundings, but we are also interested in the behavior of the employees themselves towards their surroundings.

Bachmann (2017) also points out possible methods, concepts of measuring ethical leadership. The basic method is to compile a questionnaire to identify the weaknesses of ethical leadership. Among the best-known methods are, in particular, the "Perceived Leader Integrity Scale” (PLIS) used by Craig and Gustafson (1998), Brown, Treviño and Harrison's Ethical Leadership Scale (ELS) (2005), The Corporate Ethical Virtues Model (CEV) made by Kaptein (2009).

The answers to these questionnaires can be obtained in various forms. The basic ones include a questionnaire survey among all employees, further it is possible to obtain information by means of a focus group or in-depth interviews with selected employees of the company. Each of these methods has its drawbacks. Howell (2013), Acocella (2012) or Bryman and Bell (2007) point out possible problems with the focus group method. Bachmann (2017) points out the issue of in-depth interview, where it depends very much on the quality of the interviewee (Rubin and Rubin, 2012) or Bösch (2011).

This is one of the reasons why several methods of obtaining information are proposed for the company analysis - a questionnaire survey is applied, which will affect all employees of the company. Based on this survey, in the frame of focus groups, there will be groups of employees selected, which can help the interviewer to get deeper information on the issue 
in areas that will be problematic. There will be an in-depth interview with business managers provided as the last form of data acquisition, which will help to determine management's view on individual value areas as well as their view on weaknesses, which will be identified by a questionnaire survey. Subsequent synthesis of this information helps to evaluate the determined values and eventually optimize the data by used methods. In the opinion of this article authors, some validation of the results can also be proved by selected economic and company's internal indicators. Table 1 contains selected economic and internal indicators that can be assigned to individual defined ranges of values. Insufficiently defined or non-existing processes in the company, poor communication, missing value declarations, insufficient communication or poor understanding of common interests of management and employees etc. can be demonstrated in indicators such as increased employee turnover, higher error rate, rejection rate, employee dissatisfaction etc.

Table 1. Fundamental ethical values and economic indicators.

\begin{tabular}{|c|c|}
\hline \multicolumn{2}{|l|}{ Personal values } \\
\hline Fundamental values & Economic and internal indicators \\
\hline $\begin{array}{l}\text { Freedom, self-realization at work, sufficient } \\
\text { reward for work, self-confidence by own } \\
\text { work. }\end{array}$ & $\begin{array}{l}\text { Flexibility of working hours, shifts exchange, sick- } \\
\text { days, atypical training, participation in projects, } \\
\text { career, average wage in company vs. average wage } \\
\text { in the branch, employee's fluctuation, sickness, } \\
\text { average number of overtimes. }\end{array}$ \\
\hline \multicolumn{2}{|l|}{ Organization culture values } \\
\hline Fundamental values & Economic and internal indicators \\
\hline $\begin{array}{l}\text { Communication, quality of organizational } \\
\text { culture, employer's responsibility for } \\
\text { employees, wage and career order. }\end{array}$ & $\begin{array}{l}\text { Regular meetings, frequency and periodicity of } \\
\text { rewards, fluctuation of employees in branch } \\
\text { (region). }\end{array}$ \\
\hline \multicolumn{2}{|l|}{ Consumer values } \\
\hline Fundamental values & Economic and internal indicators \\
\hline $\begin{array}{l}\text { Respecting the given processes and work } \\
\text { processes, respecting the terms, subjective } \\
\text { evaluation of quality, feedback from } \\
\text { customers. }\end{array}$ & $\begin{array}{l}\text { Investments into production means, plans } \\
\text { fulfillment, rejections, number of claims within } \\
\text { particular period. }\end{array}$ \\
\hline \multicolumn{2}{|l|}{ Social values } \\
\hline Fundamental values & Economic and internal indicators \\
\hline $\begin{array}{l}\text { Responsibility for environment, } \\
\text { responsibility for local communities, } \\
\text { responsibility for good will of organization, } \\
\text { responsibility for equal approach towards } \\
\text { human sources. }\end{array}$ & $\begin{array}{l}\text { Investments into charity, ranking of organizations } \\
\text { in branch (region), number of women/men at } \\
\text { particular positions, waste separation in } \\
\text { organization. }\end{array}$ \\
\hline
\end{tabular}

Source: own elaboration

\section{Leadership and Ethical Leadership}

In order to speak about ethical leadership, it is necessary to define ethicalaxiological bases of the man as the person. The level of organization of human society is at a high level. Yet, or precisely because of this, human society is aware of the possibilities to improve organization not only at the community level, but also in the working process. 
Human society differs from nature in a high degree of organization. They differ in the degree of organization and in that "Human Leadership differs in important ways from the pattern of dominance and submission that characterizes animal societies..." (Johnson, 2018, 21). There is still something that makes man as a species different from nature, the possibilities of his own transgression ${ }^{1}$. Human society does not differ from the animal kingdom only by being internally organized, for the animal kingdom is also organized to some extent. Transgression here means the ability of man and human society to rise above ourselves and to change our own state for the better. G.W.F. Hegel, who defined man as a subject that differs from other creatures by transcending himself. "The living substance is furthermore a being that is truly a subject, or - which means the same thing - is truly real only insofar as it is a movement of self-harmony, or a mediation between the transition of self into another being and oneself" (Hegel,1960, s. 30). This German philosopher has built ethics on the idea of a man who creates his ethos by transcending the limits of his own momentary state.

But in order to realize one's humanity, to live one's own ethos, one needs the other and the whole society, as Józef Tischner writes: "One seeks one's ethos in which one could develop and improve his bumanity. But one is fundamentally different from other living entities. The fundamental difference is that he needs other person - the whole society - to build his ethos" (Tischner, 2008, p. 3). By Tischner, it is not possible to think of a person as an individual who could not only experience his humanity but at the same time improve his life in organized society. At the same time, it is not possible to leave a certain degree of ethos and its transgression out of a society that already has a certain degree of organized character. The degree of ethos transgression in society is a prerequisite for its development. Therefore, we will consider the transgression of the ethos of society as a prerequisite. Professional literature on ethical leadership works with this assumption as well.

The very name issue of this type of management is very important. Leadership can be defined as "exercise of influence in a group context" (Johnson, 2018, p. 21). In this definition, the stress is put on "exercise of influence" in context of certain group. Similarly, Anna Putnová and Pavel Seknička define leadership as "management of people style" (Putnová and Seknička, 2016, p. 151).

Leadership has been a subject of expertise for over a hundred years. Several conceptual approaches / concepts that Bláha (Bláha, 2013) divided in accordance with leadership theories into feature theory concepts, behavioral theory, functional approach, situational or contingency approach, new leadership theories and internal and external leadership. In recent years, issues relating to the ethics of leadership have come to the forefront in theory and practice. Authors of these topics try to identify the factors that support, eventually suppress the ethical behavior of leaders. These topics / concepts of leadership include the concept of authentic leadership and servant leadership (Jarošová and Pauknerová and Lorencová, 2016). The style of authentic leadership rejects distortion and exaggeration and promotes an internalized moral perspective (the leader acts as an integrated personality), relationship transparency (confidence building) and self-awareness (reflection of his / her actions). Servant leadership can be characterized as a leadership concept that values more

1 Merriam-Webster dictionary defines the term gransgression as going beyond certain egde. In this consideration, the verb transgress is understood as a braking the particular conventions or adopting principles and as continual improvement of particular state by going beyond current state improving it. Transgress: 1 . to pass over or go beyond (a limit, boundary). s. 1505. 
honesty than profit, emphasizes ethical standards and prefers the interests of others over his / her.

A number of empirical studies have pointed out the positive consequences of authentic and servant leadership on job satisfaction and employee performance (Jarošová, 2016). These leadership concepts cannot be considered as a comprehensive concept of ethical leadership. In these concepts, the ethical dimension of leadership behavior was taken as one of the factors of the leadership styles. However, an ethical leadership approach seeks to emphasize ethics by a coherent concept that differs from other leadership concepts.

The forerunners of the ethical concept of leadership were R. Kanungo and M. Mendonca (Kanunga and Mendonca, 1996), who pointed out the ethical context of leadership in a turbulent environment and in conditions of global competition. Subsequently, J. Ciulla (Ciulla, 2004) pointed out that "good" leadership contains a pragmatic part (close to the managerial concept) as well as moral aspects that emphasize the leader's ethical responsibility for decision-making and activities. According to Ciulla, the "good" leader is both effective and ethical. The work of M. Brown, L. Treviña and D. Harrison brought a turning point in the exploration of ethical leadership. They defined ethical leadership as "demonstrating normatively appropriate behavior through personal action and interpersonal relationships and motivating coworkers to do so through the development of bidirectional communication and decision making (Brown and Treviña and Harrison, 2005).

The definition emphasizes the interaction of an ethical leader with coworkers and the ethical behavior of the leader. The problematic part of the definition is "normatively equivalent behavior". Should such behaviour be normatively corresponding to universal ethical principles and norms or rather to normatively corresponding behavior set in the organization by ethical code, HR policy or other normative documents?

In the forthcoming multidimensional analysis of ethical leadership, the authors of the article inclined to define appropriate ethical behavior, which is given by normative documents in organizations in which they expect to provide research into ethical leadership. Therefore, the authors also consider that based on the research, documents will be elaborated or modified related to ethical leadership. Ethical leadership is also dealt with by E. Johnson. First it defines the concept of leadership and then the term ethical leadership (Johnson, 2018, p. 22):

- direction determination,

- organizing,

- activities coordination,

- resources coordination,

- motivation,

- conflicts management.

However, these six points are not yet sufficient to consider the leadership ethical. Johnson adds that "ethical leadership practice consists of a two-stage process requiring personal moral behaviour and moral influencing" (Johnson, 2018, p. 23). Ethical leadership requires managers to identify with and act on a certain morality. And furthermore, requires them to influence their surroundings by personified values. Johnson further enumerates these values. By ethical leadership we understand the kind of leadership that can be attributed to the following features (Johnson, 2018, p. 23): 
- justice,

- humanity,

- optimism,

- courage,

- empathy.

We believe that this particular style of leadership will have a positive impact not only on organizational culture (Rolný, 2014), but also on the development of the company's human capital and thus on its economic performance in the emerging industry 4.0.

\section{Ethical Leadership and Human Capital}

At the same time, with the fourth phase of the industrial revolution many unknowns come. It is not clear what Industry 4.0 will look like. It is also a great unknown how the labour market will change in the fourth phase of the industrial revolution. But what is possible is a certain prediction based on data. It can already be said that the fourth industrial revolution will be based on the gradual computerization of production processes.

Carl B. Frey and Michael A. Osbourne (2017) in their work The Future of Employment: How Susceptible are Jobs to Computerization? show what impact the computerization will have on development of the labour market. In their article, they show the percentage of danger certain occupations will face. At the same time, they point out jobs that will be irreplaceable by machines, robots and artificial intelligence. In other words, professions for which the man is necessary. Not only knowledge and skills will play a big role, but also soft skills that no machine and artificial intelligence can replace. Among other things, abilities that make the man human such as empathy, empathetic leadership.

Therefore, the answer to the question Why engage in ethical leadership? is quite clear. Innovation and the development of new technologies do not go hand in hand with all aspects and impacts they may have on society. Creativity (idea) alternates technical thinking (product realization). What is missing in this process are urgent questions (responsibility, conscience, etc.) that should be asked before and during implementation and should be closely linked to everything related to a knowledge-based society. It is this society that realizes the importance of the intellectual capital of a company.

If we want to understand ethical leadership in the broadest possible context, i.e. multidimensionally and analyze it from the perspective of social and individual values, we have to realize that the specific outcomes that define individual businesses are based on three components of intellectual capital. It consists of: human, organizational and customer capital.

According to Skrzypek (2002, p. 691), "Intellectual capital is a non-financial asset. It is the sum of the knowledge that people own within the company and the ability to use that knowledge for the benefit of company development, which in turn transfers into company efficiency".

The most important part of intellectual capital is human capital, which Edvinsson and Malone (2001, p. 17) define as: "The combined knowledge, skills, innovativeness and ability of individual company employees to perform their tasks effectively".

The interaction of all elements of human capital results in organizational capital. According to Baron, Armstrong (2008, p. 27), "Organizational (structural) capital includes 
knowledge that is the property of an organization, not of individual employees. This knowledge can be characterized as embedded or institutionalized and can be stored in easily accessible and easily extensible databases using information technology ".

Equally important is customer capital. By Barták (2006, p. 27), "it represents knowledge of what customers want or will want. Knowledge of their needs, wishes, aspirations, desires, preferences, expectations, quantitative and qualitative requirements for existing and prospective products or services the basis not only for reactive but also proactive satisfaction of anticipated customer needs".

To determine the level of the current state of multidimensional ethical leadership, we will consider all the components of the company's intellectual capital. To make the analysis, among others, tools such as questionnaire, semi-structured interview, focus group, which will also affect suppliers and customers will be used. These and other content-tailored tools for exploring social and individual values allow to provide their sufficient (detailed) analysis. Obtained facts predetermine ways to implement improvements in individual areas, capitals.

The knowledge society has moved the 21 st century into a new industrial revolution. We also call it Industry 4.0. According to Korbel (2015), "The Fourth Industrial Revolution is represented by cyber-physical systems that will create" smart factories ". Smart devices will take over some of the activities that people have done. Methods of machine perception, self-configuration and self-diagnostics, and computer connection of machines and parts are envisaged." Technologies are being modernized and transformed with cyber systems, the Internet of Things or cloud computing.

Start-ups focus on the realization of more recently futuristic themes. The new era, the new industrial revolution, requires the "closure" from the ethical point of view of the third industrial revolution. Current research data can be used for this purpose. The present also requires answers to a question that has not yet been given proper attention: what role will ethics and ethical leadership play in the next industrial revolution in the coming decades? This question must be asked to start-ups as well as to all other, manufacturing and nonmanufacturing companies and multinational corporations as well. The answers must also be sought from academics and perhaps the general public. Human capital creates the Industry 4.0, but at the same time it positively and negatively changes the world of its users. Some jobs will disappear, others significantly change their content. It will change architecture, culture, relationships, ways of communication, etc. These and other changes will be perceived both positively and negatively. Ethical leadership should minimize the negative impacts of Industry 4.0 and prevent from them.

It is a good sign that small and large companies are looking for a morally mature leader in this anomic era. It turns out that moral maturity is still a recognizable value.

\section{Pilot Research}

The research team verified in the form of a pilot research whether the prepared research will be comprehensible to the respondents and whether the obtained results will be informative, on the basis of which concrete measures can be formulated. Only ethical values were chosen for the pilot research, so there was no comparison with economic indicators provided; comparison will be provided within the research realization.

As mentioned above, the recognition of individual values within a company and the level of ethical leadership can be identified using the methods outlined above. Based on studies 
by Bachmann (2017), Craig and Gustafson (1998), Brown, Treviño and Harrison (2005), a questionnaire was prepared that included questions about ethical leadership and each question was given a value in the particular area. ${ }^{2}$

Each question contained 4 answers that were scored. In the case of a positive answer and thus assuming that the values are well set and respected in the company, a value of 4 was assigned. For each question the average value was calculated representing thus the majority opinion in the company. If the average value per question falls below 3 points, we conclude that this value is perceived inadequately in the company or is partially or completely disturbed. The answers to the questions can then be displayed graphically in different ways (see Graphs 1 and 2). In case of a bar graph, problem areas can be presented with a different color (e.g. red). In case of a cobweb graph, it is possible to observe the distance (diversion) from a regular multi-angle, where the ideal state is the extreme (marginal) multiangle. The greater the distance from the boundary, the more problematic the value in the company is.

After completing this questionnaire, a pilot study was carried out to verify the correctness of questions (mainly from the point of view of respondents' understanding). The questionnaire survey was carried out in a small engineering company with 10 employees. Prior to the questionnaire survey, an interview was conducted with the company director, who pointed out the high job changing in the company, which was around $20 \%$, low cooperation among employees, communication noise, which led to the overall dissatisfaction of employees. Based on this information and knowledge of some economic and internal indicators, it was assumed that the company has the greatest problems in the area of individual and social values (see Graph 1).

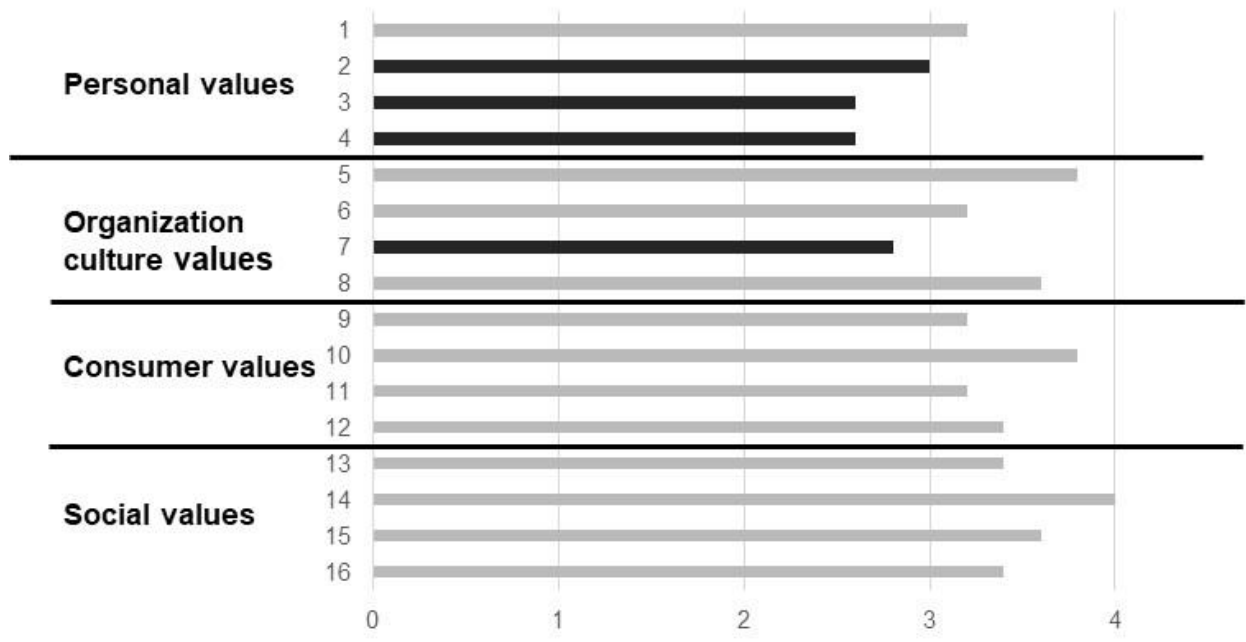

Graph 1: Bar presentation of answers to questionnaire questions

Source: own elaboration

2 In our primary research, one question was assigned to each value. In the future, each value can involve more questions; certain symmetry should become a presumption, i.e. the same number of questions should be assigned to each value 
This assumption has been confirmed. This means that the weakest area in the company the personal values are being understood from the position of employees quite inadequately. Organization culture weaknesses are another weak point in the company (see Graphs 1 and 2). On the contrary, the area of consumer and social values is understood by employees in the company at a very good level.

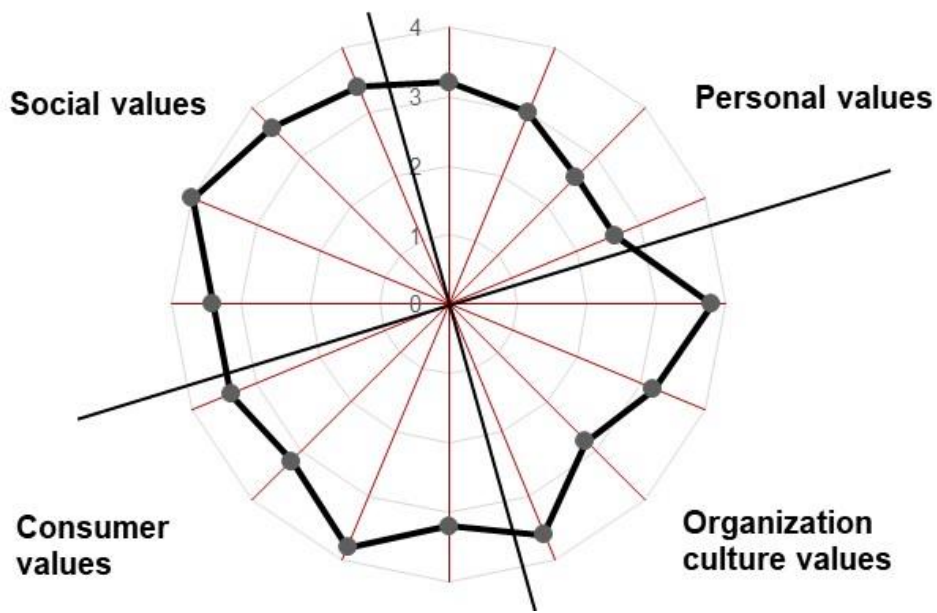

Graph 2: Cobweb presentation of answers to questionnaire questions

Source: own elaboration

Based on the survey, changes that should lead to greater employee satisfaction in the area of personal and organization culture values ${ }^{3}$ were proposed to the company director.

As stated above, this primary research was primarily aimed at piloting the questions raised. Respondents had problems with six questions and the answers were not clearly defined. Therefore, these questions have been adjusted so that respondents can clearly understand them. This modified questionnaire will then be used in another survey - this time in a large company with more than a thousand respondents.

The primary research confirmed a certain interconnection of economic or company's internal indicators with defined values. Thus, weaknesses in the area of personal, consumer or cultural values can be predicted based on problems in these figures. Based on the interconnection of values defined by us with the values of ethical leadership, it is possible to point out the strengths and weaknesses of ethical leadership and thus of the whole company. Based on these findings, measures can also be proposed that should

3 These changes dealt with a determination of precise work description for each employee, transparent rewarding (i.e. employees know what kind of reward they can get and for what). Company director set regular meetings taking place more often as well as he started to communicate successes and problems of company with employees. Even the company is very small, the director also outlined some options of career advancement, which made employees to be more motivated. Basic processes were set and described as well, which the employees can follow in particular situations. Once those changes are implemented, there will be another questioning realized in order to prove whether situation improved or not. The first economic and internal indicators show the improvement in those areas. 
strengthen the identified weaknesses.

Based on this pilot study, the validity of ethical values as well as the clarity of the research questions were verified. We think that the value system is comprehensible and comparable with economic indicators in the way we designed it. The results of the pilot study showed the suitability of this method for the upcoming research.

\section{Acknowledgement}

The article was elaborated within the SGS project at the Faculty of Economics, VŠB - TU Ostrava, project No. SP2019/7.

\section{References}

Acocella, I. (2012). The focus groups in social research: Advantages and disadvantages. Quality and Quantity, 46(4), 1125-1136.

Anzenbacher, A. (1991). Úvod do filozofie. Státní pedagogické nakladatelství, Praha. pp. 251-252.

Bachmann, B. (2017). Ethical Leadership in Organizations. Springer International Publishing.

Baron, A. and Armstrong, M. (2008). Zarządzanie kapitałem ludzkim. Wolters Kluwer Polska Sp. z o.o., Kraków. pp. 27.

Barták, J. (2006). Skryté bohatství firmy. Alfa Publishing, s.r.o., Praha. pp. 27.

Bláha, J. (2013). Pokročilé ŕízení lidských zdrojů. Edika, Brno. pp. 152-170.

Bösch, W. (2011). Praxishandbuch Mitarbeiterbefragungen. Praxium, Zürich.

Brown, M. E. and Treviño, L.K. and Harrison, D. A. (2005). Ethical leadership: A social learning perspective for construct development and testing. Elsevier, Amsterdam. pp. 117-134.

Bryman, A., Bell, E. and Harley, B. (2018). Business research methods (5th ed.). Oxford: Oxford University Press.

e.g. Business Leaders Forum, What is CSR?

Ciulla, J. (2004). Ethics and Leadership Effectiveness. In: Antonakis, J. and Cianciolo, A.T. and Sternberg, R.J. The Nature of Leadership. (2004) SAGE Publications: Thousand Oaks. pp. 302-328.

Craig, S. B., and Gustafson, S. B. (1998). Perceived ledership integrity scale: An instrument for assesing employee perceptions of leader integrity. Leadership Quaterly, 9(2), pp. $127-145$.

Edvisson, L., and Malone, M.S. (2001). Kapitał intelektualny. Wydawnictwo Naukowe PWN, Warszawa. pp.17.

Freeman, R.E. (2005). A Stakeholder Theory of the Modern Corporation. In: Hartman, L.P. (ed): Perspectives in Business Ethics. McGraw-Hill, Boston. pp. 1-80.

Frey, C.B. and Osborne, M.A. (2017). The Future of Employment: How susceptible are Jobs to Computerisation? Technological Forecasting and Sociological Change, Amsterdam. pp. 254-280

Hegel, W.F.G. (1960). Fenomenologie Ducha. Nakladatelství Československé akademie věd, Praha. pp. 30.

Howell, K. E. (2013). An introduction to the philosophy of methodology. Sage publication, London.

Jarošová, E. and Lorenová, H. and Puknerová. P. (2017) Nové trendy v leadershipu. Management Press, Praha. pp. 114-131.

Johnson, E. C. (2018). Meeting the Ethical Challenges of Leadership. Casting Light or Shadow. Sage publication, Los Angeles. pp. 21-23.

Kanungo, R. and Mendoca, M. (1996). Ethical Dimension of Leadership. Sage Publications, London. pp. 10-31.

e.g. Korbel, P. (2015). Průmyslová revoluce 4.0: Za 10 let se továrny budou rídit samy a produktivita vzroste o třetinu. Lidové noviny, Praha.

Ochrana, F. (2009). Metodologie vědy. Úvod do problému. Karolinum, Praha. pp. 13-68.

Putnová, A. and Seknička, P. (2016). Etika v podnikání a hodnoty trhu. Grada, pp.150-151.

Rolný, I. (2014). Budujeme důvěryhodnou firmu. C.H.Beck, Praha. pp. 113-117.

Rubin, H. J., \& Rubin, I. S. (2012). Qualitative interviews. The art of hearing data (3rd ed.). Thousand Oaks, Sage publication. 
Skrzypek, E. (2002). Miejsce zarządzania informacją i wiedzą w strategii przedsiębiorstwa. In: Stabryła, A. Zarządzanie firmą w społeczeństwie informacyjnym. Kraków: Akademia Ekonomiczna w Krakowie, Kraków. pp. 691.

Tischner, J. (2008). Etyka a historia. Wykłady. Instytut myśli Józefa Tischnera, Kraków. pp. 3.

Webster's Encyclopedic Unabridged Dictionary of the English Language (1994). Gramercy Book: New Jersey. pp. 1505. 